\title{
A study of the microbiological and physico-chemical quality of drinking water intended for human consumption in the town of Kenitra
}

\author{
Latifa Benakka ${ }^{1,}{ }^{*}$, Loubna Zogaam Gharbi ${ }^{2}$, Morad Guennouni ${ }^{3}$, Zohra Bejjaji ${ }^{1}$, and Mahjoub Aouane ${ }^{2}$ \\ ${ }^{1}$ Laboratory Geosciences of Natural Resources, Faculty of Sciences IbnTofail University Kenitra Morocco. \\ ${ }^{2}$ Laboratory Agroresource Biotechnology Environment and Quality, Faculty of Sciences, IbnTofail University, Kenitra, Morocco. \\ ${ }^{3}$ Laboratory of Health Sciences and Technologies, Higher Institute of Health Sciences of Settat, Faculty of Science and Technology of \\ Setta, Morocco.
}

\begin{abstract}
The quality of drinking water is highly dependent on physico-chemical and microbiological characteristics. This study envisaged to determine the physico-chemical and microbiological quality of the water consumed by the population of the town of Kenitra by analyzing the following parameters: Conductivity, Turbidity, Temperature, pH, Sulphates, Cadmium, Selenium, Arsenic, Fluorides, Total Iron, Manganese, Chloride Ions, Nitrates, Nitrites, Cadmium, Boron, Nickel, Trihalomethanes, Ammonium and Potassium Permanganate. On the other hand by analyzing the following microbiological parameters: Escherichia coli, intestinal enterococci, coliforms and revivifiable microorganisms at $22^{\circ} \mathrm{C}$ and $37^{\circ} \mathrm{C}$. In general, biological contamination was not detected in the samples collected from Kenitra. At the same time, the results of some physico-chemical elements do not also show contamination in drinking water, which implies that the concentrations of these elements are perfectly in line with WHO requirements.Indeed, the physico-chemical parameters that were considered non-compliant in this work are temperature, $\mathrm{pH}$, dissolved $\mathrm{O} 2$ and sulfate (SO42-) represent an impact on water. The results obtained were found to be below the values required by the Moroccan standard.
\end{abstract}

\section{Introduction}

Fresh water is a fundamental element for the life of man and living beings. In nature, man needs a very large amount of water for consumption - 25 to $50 \mathrm{~g}$ of water per kilogram of his weight to live under normal conditions. However, the microbiological phenomena that exist in drinking water, in particular the presence of pathogenic microorganisms, affect water quality on several levels (taste, odors, etc.)[1].

Climate change is a major factor on freshwater. For a long time, several studies and indicators have corroborated that the climate is warming on a global scale. The fourth report (2007) of the Intergovernmental Panel on Climate Change (IPCC) confirms this fact. [2].

On the other hand, climate change has an effect on surface and ground water resources, which are linked to seasons of intentional changes in river flow with the lowering of snow cover [2].

The development of water resources must make it possible to ensure the availability of sufficient water in quantity and quality for the benefit of all users in accordance with the aspirations of harmonious economic and social development, the orientations of national land use plans and the possibilities offered by water potentialities for their development and this, at a lower cost [3].
Assessing drinking water quality based on water quality data is a very important and critical thing. In general, to analyze water quality people in the field make their decision by comparing individual parameters with recommended values, however, this decision remains incomplete [4].

The availability of good quality drinking water is a major focus for every human being living on earth. That is why several studies have been carried out in this subject, for example, and based on the results of some authors concerning the elements evaluated in water, they found that the concentration of fluoride was 0 to 3.45 $\mathrm{mg} / \mathrm{L}$, and on average $323.376 \pm 0.05 \mathrm{mg} / \mathrm{L}$ and the concentration of nitrates was 0 to $218 \mathrm{mg} / \mathrm{L}$ and on average $3.58 \pm 1.1 \mathrm{mg} / \mathrm{L}$ [5]. In parallel, the concentration of some of the following parameters: $\mathrm{pH}$ (7.2-7.7), manganese $(\mathrm{Mn} 2+)(0.00 \mathrm{e} 0.01 \mathrm{mg} / \mathrm{L})$, iron $(\mathrm{Fe} 2+)(0.00 \mathrm{e} 0.09 \mathrm{mg} / \mathrm{L})$, sulfate (SO42-) $(0.00 \mathrm{e} 172,8$ $\mathrm{mg} / \mathrm{L})$ and copper $(\mathrm{Cu} 2+)(0.00 \mathrm{e} 0,04 \mathrm{mg} / \mathrm{L})$ were found to be below the limit values set by the WHO [6].

The main purpose of this article is the evaluation of the quality of the drinking water taken from the region of El Gharb, using microbiological and physico-chemical methods to analyze and measure some elements such as: coliforms, Escherichia Coli, pH, nitrates, temperature...also, the results found were processed by the IBM SPSS software to evaluate the significance.

\footnotetext{
"Corresponding author: latifa.benakka@uit.ac.ma
} 


\section{Materials and methods}

\subsection{Study environment and site}

Kenitra is located in the northwest of Morocco near the Atlantic Ocean (40 km north of Rabat) This city is built on the bank of OuedSebou, which has its source in the Middle Atlas and in the length is about $500 \mathrm{~km}[13]$.

Kenitra is the chief town of the GHARB region, a rich agricultural region, watered by the Sebouriver and its tributaries, it is located near the railroad that runs along the coast, it has an important port, a first class naval base, textile factories, fish processing units, fertilizer and tobacco factories.

The region is also endowed with a very important agricultural richness, a forest heritage very noticed by the abundance of the cork chain, and natural zinc resources which are essentially extracted in the East of Kenitra.

\subsection{Microbiological analyses}

Generally speaking, bacteriological analysis is linked to efficient microbiological culture techniques.

\section{Escherichia coli}

Coliform bacteria were measured by the membrane filtration method and which also produce indole from Tryptophan within $(21 \pm 3) \mathrm{h}$ at $(44 \pm 0.5){ }^{\circ} \mathrm{C}$ (NM ISO 9308-1/2007). [9]

\section{Intestinal enterococci}

Enterococci are bacteria were measured by sterile membrane filtration and incubated for $(36 \pm 2){ }^{\circ} \mathrm{C}$ at $(44$ $\pm 4) \mathrm{h}$ on Slanetz and Bartely medium. In contrast, incubate for $(44 \pm 0.5){ }^{\circ} \mathrm{C}$ at $2 \mathrm{~h}$ on bile medium esculinazide Enumeration of typical colonies according to ISO7899-2/2007 [11]

\section{Revivable microorganisms}

The revivifiable microorganisms were analyzed by the colony counting method by inoculation in agar culture medium and incubated aerobically at $(36 \pm 2){ }^{\circ} \mathrm{C}$ for $(44 \pm 4) \mathrm{h}$ and $(22 \pm 2){ }^{\circ} \mathrm{C}$ for $(68 \pm 4) \mathrm{h}$ colony counting, according to the Moroccan standard ISO 6222/2007. [10]

\section{Coliforms}

Total coliforms (TC) were analyzed by the membrane filtration method. This membrane was deposited on the TTC lactose agar and the sodium humidifier. Incubation was carried out at a temperature of $(36 \pm 2){ }^{\circ} \mathrm{C}$ for a period of $(21 \pm 3) \mathrm{h}$ according to the Moroccan standard ISO 9308-1. [9]

\subsection{Physico-chemical analyses}

Several physico-chemical analyses were involved outside of this study, examples of the measured parameters and methods used according to Moroccan standard NM 03.7.001
- $\mathrm{pH}$ : The hydrogen potential $(\mathrm{pH})$ is measured using a $\mathrm{pH}$ meter type $\mathrm{HACH}$.

- The temperature of the water: it is measured by means of an ordinary mercury thermometer graduated in tenth

- Conductivity: is measured by a conductivity meter of the HACH type.

- Turbidity: is measured by a HACH-type turbidity meter.

- Chloride: are measured by titrimetry

- Oxidability: oxidation by potassium dichromate (K2Cr2O7) in acid and boiling environments.

- Sulphate: is measured by gravimetry

- Iron: measured by flame photometry

- Manganese: is measured by Atomic absorption spectrometry with flame

- Arsenic, selenium and cadmium: are measured by atomic absorption spectrometry with furnace.

- Fluoride: is measured by the specific electrochemical method

- Ammonium: on the filtered sample, it is determined by the colorimetric method with indophenol blue in alkaline medium.

- Boron: is measured by Molecular Absorption Spectrometry

- Nickel: Flame Atomic Absorption Spectrometry

- Nitrates/ Nitrites: are measured by Molecular Absorption Spectrometry.

- Trihalomethanes -Gas chromatography

\section{Result and discussion}

All the results of our study data were processed by the SPSS software. We performed daily sampling using methods that detect microbiological and physicochemical substances during the years 2017, 2018 and 2019.

\subsection{Microbiological analyses}

For the microbiological analyses, we have tested for the presence of five microorganisms in our drinking water samples, and are as follows: Escherichiacoli, Intestinal Enterococci, Coliform, Revivifiable Microorganism at $22^{\circ} \mathrm{C} / 1 \mathrm{ml}$, and Revivifiable Microorganism at $37^{\circ} \mathrm{C} / 1 \mathrm{ml}$.

The results obtained from the analysis of escherichia coli, intestinal enterococci and coliforms do not detect these substances in samples from the three years 2017, 2018 and 2019. Therefore, it can be said that there is no contamination from these elements. Our results differ from those reported by Khalid et al, as they found, based on microbiological analyses of the drinking water samples, that the groundwater in Blocks C, D and F was contaminated with E. coli and coliforms and in the rest of the water did not show any contamination.

Similarly, Mehmood et al reported that water tests conducted in Islamabad revealed the presence of coliforms in all water samples, while $50 \%$ of the samples detected the presence of Escherichia Coli [7].

According to Table 1, the results obtained from statistical analysis indicate that the microorganisms 
revivifiable at $22^{\circ} \mathrm{C}$ and $37^{\circ} \mathrm{C}$ are not significant, which explains that these substances do not present a source of contamination of drinking water.

Table 1. Content of revivifiable microorganisms at $22^{\circ} \mathrm{C}$ and $37^{\circ} \mathrm{C}$ in the years 2017,2018 and 2019

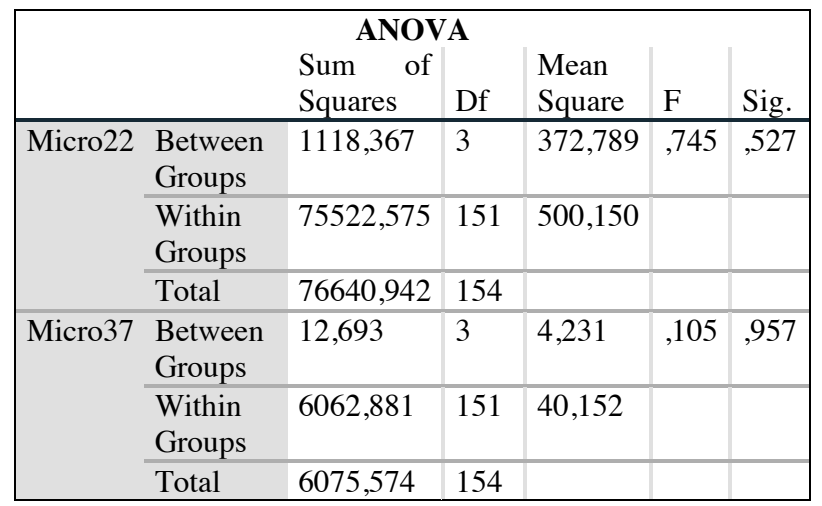

\subsection{Physico-chemical analyses}

Concerning the elements analyzed in this part, it was found according to the ANOVA (Table 2) that $\mathrm{pH}$, temperature, dissolved oxygen and sulfate (SO42-) are significant. This allows us to conclude that there is an influence of these substances on the quality of drinking water in relation to the years 2017, 2018 and 2019.

Our found results are similar to what the author announced Khalid [6], who said that for all sampling sites the $\mathrm{pH}(7.2-7.7)$ and sulfate (SO4 2) (0.00-172.8 $\mathrm{mg} / \mathrm{L}$ ) were found below the limits set by the WHO [6].

The same results were observed by (Afify D.G. AlAfify and Mohamed y. Mohamed) that the dissolved oxygen (DO) was within the limits of Egyptian and WHO drinking water standards [12].

In Tables 3 and 4, there are two examples of correlation at 0.01 ; one of temperature with years and the other of $\mathrm{pH}$ with years which are obtained by the SPSS software.

On the other hand, fig. 1 represents in a global way the impact of these four substances on our samples compared to the years 2017, 2018 and 2019. For example, we can see that temperature has a major effect in the year 2019 compared to the other years, as well as in the year 2019 we can see that there is a well distinguished influence of sulfate when comparing with the years 2017 and 2018 .

Table 2. Representation of temperature, $\mathrm{pH}$, dissolved oxygen and sulfate concentrations in the three years 2017, 2018 and 2019

\begin{tabular}{|c|c|c|c|c|c|c|}
\hline \multicolumn{7}{|c|}{ ANOVA } \\
\hline & & Sum of Squares & Df & Mean Square & $\mathrm{F}$ & Sig. \\
\hline \multirow[t]{3}{*}{$\mathrm{PH}$} & Between Groups & 8,436 & 3 & 2,812 & 50,367 & ,000 \\
\hline & Within Groups & 8,821 & 158 & 056 & & \\
\hline & Total & 17,258 & 161 & & & \\
\hline \multirow[t]{3}{*}{ Temperature } & Between Groups & 50,815 & 3 & 16,938 & 4,786 & ,003 \\
\hline & Within Groups & 559,142 & 158 & 3,539 & & \\
\hline & Total & 609,957 & 161 & & & \\
\hline \multirow[t]{3}{*}{ O2.dissolve } & Between Groups & 3,394 & 3 & 1,131 & 6,892 & 000 \\
\hline & Within Groups & 9,520 & 58 & ,164 & & \\
\hline & Total & 12,914 & 61 & & & \\
\hline \multirow[t]{3}{*}{$\mathrm{SO} 4$} & Between Groups & 451,080 & 3 & 150,360 & 4,165 & 010 \\
\hline & Within Groups & 2093,795 & 58 & 36,100 & & \\
\hline & Total & 2544,875 & 61 & & & \\
\hline
\end{tabular}

Table 3. Temperature variation correlated with years 2017 2018 and 2019

\begin{tabular}{|c|c|c|c|}
\hline \multicolumn{4}{|c|}{ Correlations } \\
\hline & & $\begin{array}{l}\text { Time of } \\
\text { sampling }\end{array}$ & Temperature \\
\hline \multirow[t]{3}{*}{$\begin{array}{l}\text { Time } \\
\text { sampling }\end{array}$} & $\begin{array}{l}\text { Pearson } \\
\text { Correlation }\end{array}$ & 1 & $216^{* *}$ \\
\hline & Sig. (2-tailed) & & ,006 \\
\hline & $\mathrm{N}$ & 165 & 162 \\
\hline \multirow[t]{3}{*}{ Temperature } & $\begin{array}{l}\text { Pearson } \\
\text { Correlation }\end{array}$ &, $216^{* *}$ & 1 \\
\hline & Sig. (2-tailed) & ,006 & \\
\hline & $\mathrm{N}$ & 162 & 162 \\
\hline
\end{tabular}

Table 4. pH variation correlating with years 2017, 2018 and 2019

\begin{tabular}{|c|c|c|c|}
\hline \multicolumn{4}{|c|}{ Correlations } \\
\hline & & Timeofsampling & PH \\
\hline \multirow[t]{3}{*}{ Time of sampling } & $\begin{array}{l}\text { Pearson } \\
\text { Correlation }\end{array}$ & 1 & $571^{* * *}$ \\
\hline & Sig. (2-tailed) & &, 000 \\
\hline & $\mathrm{N}$ & 165 & 162 \\
\hline \multirow[t]{3}{*}{$\mathrm{PH}$} & $\begin{array}{l}\text { Pearson } \\
\text { Correlation }\end{array}$ &, $571^{* *}$ & 1 \\
\hline & Sig. (2-tailed) & 000 & \\
\hline & $\mathrm{N}$ & 162 & 162 \\
\hline
\end{tabular}




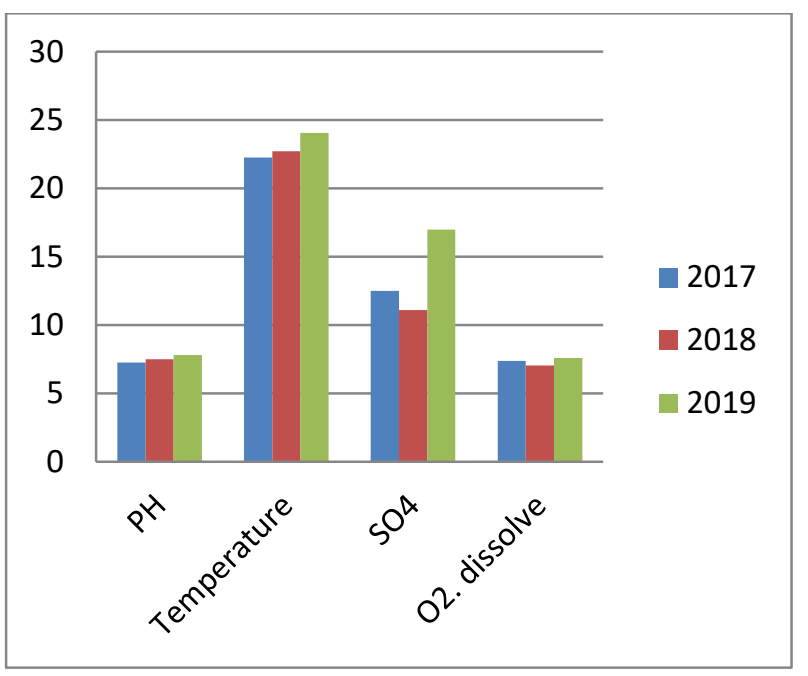

Figure.1. Comparison of the parameters: $\mathrm{pH}$, temperature, sulfates and dissolved oxygen during the years 2017, 2018 and 2019.

According to table 5 the results of these elements were reported that the physico-chemical substances are not significant, which explains why the concentrations of these substances do not cause a problem on the quality of drinking water.

Our found results differed from what announced by Khalid et al, who revealed that the values of some parameters such as Electrical conductivity, Chloride $(\mathrm{Cl})$ and Nitrate were respectively $(0.34 \mathrm{e} 2,23 \mathrm{mS} / \mathrm{cm})$,
$(0.00 \mathrm{e} 479,25 \mathrm{mg} / \mathrm{L})$ and $(0.59 \mathrm{e} 12,14 \mathrm{mg} / \mathrm{L})$ exceed the WHO limits. [6].

Thus our results differ from what presented by $\mathrm{S}$. Ponsadai Lakshmi and all who detected that the fluoride concentration exceeds the WHO limits [4].

Same results are found according to Virginie GBOHAIDA and all reported that all water samples analyzed had turbidity values between 0 and 1 NTU, according to the standard. Dassa water showed no turbidity, so it was reported that the results for ammonium (NH4+) and nitrite (NO2-) ions were very low, indicating good water quality. [14].

For the other physico-chemical elements, was remarkable that the contamination of water by oxide $\mathrm{KMnO} 4$ and dissolved $\mathrm{Fe}$ is generally less than $<0.005$ our results found are similar to what announced by Khalid et al, who showed that iron $(0.00 \mathrm{e} 0,09 \mathrm{mg} / \mathrm{L})$, were found below the limits set by the WHO, [6]. This contamination level was less than $<3$ for As and Se. For water contamination by $\mathrm{Cd}$, the level was between 0.024 and 1 and was less than 1 for $\mathrm{Ni}$.

However, Mansour Ghaderpoori et al. reported that the average cadmium concentration is $0.42 \mu \mathrm{g} / 1$ [15].

These results are contrary to those of El Yemli et al. which revealed that the concentration of nickel $[\mathrm{Ni}+]$ in the waters studied varies between $0 \mu \mathrm{g} / \mathrm{L}$ in the stations $(\mathrm{S} 3, \mathrm{~S} 4, \mathrm{~S} 5, \mathrm{~S} 6, \mathrm{~S} 8)$ as a minimum value of zero and 10 $\mu \mathrm{g} / \mathrm{L}$ for the stations $(\mathrm{S} 1, \mathrm{~S} 2, \mathrm{~S} 7)$ as a maximum value in winter period and varies between $0 \mu \mathrm{g} / \mathrm{L}$ for (S2, S4, S5, S6, S8) and $3 \mu \mathrm{g} / \mathrm{L}$ for (S1) [16].

Table 5. Representation of the ANOVA

\begin{tabular}{|c|c|c|c|c|c|c|}
\hline \multicolumn{7}{|c|}{ ANOVA } \\
\hline & & Sum of Squares & df & Mean Square & $\mathrm{F}$ & Sig. \\
\hline \multirow[t]{3}{*}{ Turbidité } & Between Groups & 3,363 & 3 & 1,121 & 1,362 & 256 \\
\hline & Within Groups & 129,999 & 158 &, 823 & & \\
\hline & Total & 133,362 & 161 & & & \\
\hline \multirow[t]{3}{*}{ Conductivité } & Between Groups & 19141,760 & 3 & 6380,587 & 484 & 694 \\
\hline & Within Groups & 2084769,771 & 158 & 13194,745 & & \\
\hline & Total & 2103911,531 & 161 & & & \\
\hline \multirow[t]{3}{*}{ NH4 } & Between Groups &, 000 & 1 & ,000 & ,177 & ,679 \\
\hline & Within Groups &, 000 & 19 & ,000 & & \\
\hline & Total & ,000 & 20 & & & \\
\hline \multirow[t]{3}{*}{$\mathrm{Cl}$} & Between Groups & 2610,471 & 3 & 870,157 & 1,430 & 243 \\
\hline & Within Groups & 35300,365 & 58 & 608,627 & & \\
\hline & Total & 37910,837 & 61 & & & \\
\hline \multirow[t]{3}{*}{ NO3 } & Between Groups & 655,654 & 3 & 218,551 & 1,168 & ,324 \\
\hline & Within Groups & 28078,023 & 150 & 187,187 & & \\
\hline & Total & 28733,677 & 153 & & & \\
\hline \multirow[t]{3}{*}{$\mathrm{NO} 2$} & Between Groups & ,000 & 1 & ,000 & ,296 & ,593 \\
\hline & Within Groups &, 000 & 19 &, 000 & & \\
\hline & Total &, 000 & 20 & & & \\
\hline \multirow[t]{3}{*}{$\mathrm{F}$} & Between Groups & ,006 & 2 & ,003 & 854 & ,434 \\
\hline & Within Groups &, 143 & 39 &, 004 & & \\
\hline & Total &, 150 & 41 & & & \\
\hline
\end{tabular}




\section{Conclusion}

Water is an indispensable and precious element for human life. Water intended for human consumption requires a better physico-chemical and microbiological quality.

The results of the microbiological analyses of this study show the absence of Escherichia coli, intestinal enterococci, coliforms and the detection of concentrations of revivifiable microorganisms at $22{ }^{\circ} \mathrm{C}$ and $37^{\circ} \mathrm{C}$ below the values required by the Moroccan standard. This is particularly true of a lack of water contamination.

Nevertheless, the results of the physico-chemical analyses carried out have demonstrated the existence of certain parameters in our samples which are temperature, $\mathrm{pH}$, dissolved oxygen and sulfate which can be considered as substances influencing the quality of drinking water. In parallel there are other physicochemical parameters that are revealed to be insignificant, and that their concentrations are in accordance with the Moroccan standard, such as turbidity, electrical conductivity, ammonium, chloride ions, nitrates, nitrites and dissolved iron.As well as acceptable concentration values have been found for the following elements potassium permanganate dioxide (KMNO4), arsenic (As), selenium (Se) and cardium (Cd) and nickel (Ni). This could explain the absence of contamination of our drinking water samples.

\section{References}

1. C.M.Bourgeois, J. M. Microbiologie alimentaire. TOME 1/Aspect microbiologique de la sécurité et de la qualité des aliments, (1996).

2. N.W. Arnell. Relative effects of multi-decadal climatic variability and changes in the mean and variability of climate due to global warming: future stream flows in Britain. J. Hydrol. 270:195-213. (2003)

3. Cahier de Ministre délégué auprès du Ministre de l'énergie, des Mines, de l'Eau et de l'Environnement chargé de l'Eau.

4. S. Ponsadai Lakshmi, S. GanapathySankari, S. MythiliPrasanna and G. Madhurambal, "Evaluation of Water Quality Suitability for Drinking using Drinking Water Quality Index in Nagapattinamdistrict,Tamil Nadu in Southern India", Groundwater for Sustainable Development, https://doi.org/10.1016/j.gsd.(2017)

5. M. Radfard, H. Soleimani, A. Azhdarpoor, H. Faraji and A.H. Mahvi, Dataset on assessment of physical and chemical quality of groundwater in rural drinking water, west Azerbaijan Province in Iran. (2018)

6. S. Khalid, B. Murtazaa, I. Shaheena, I. Ahmad, M. IrfanUllahb , T. Abbas, F. Rehmand, M. Rizwan Ashraf, S. Khalid, S. Abbas, M. Imrana. Assessment and public perception of drinking water quality and safety in district Vehari, Punjab, Pakistan. Journal of
CleanerProduction .volume 181.2018, pages 244 234.https://doi.org/10.1016/j.jclepro.(2018)

7. Mahmoud, S., Ahmad, A., Ahmed, A., Khalid, N., Javed, T. Drinking water quality in capital city of Pakistan.Sci.Rep.2, 637. 10.4172/scientificreports.637. Midrar-Ul-Haq, Khattak, R.A., Puno, H.K., Saif, M.S., Memon, K.S., 2005. Surface and ground water contamination in NWFP and Sindh provinces with respect to trace elements. Int. J. Agric. Biol. 7, 214e217. (2013)

8. Cude, C.G. Oregon water quality index: a tool for evaluating water quality management effectiveness. Journal of the American Water Resource Association, 37 (1): 125-137. (2001)

9. NM ISO 9308-1/2007 ; Indice de classement NM 03.7 .003 : Qualité de l'eau-Recherche et dénombrement des Escherichia coli et des bactéries coliformes ; Partie 1: Méthode par filtration sur membrane

10. NM ISO 6222/2007, indice de classement NM 03.7.005, Qualité de l'eau-Recherche et dénombrement des micro-organismes dans les eaux d'alimentation humaine : comptage des colonies par ensemencement dans un milieu de culture nutritif gélosé

11. NM ISO 7899-2/2007; indice de classement NM 07.3.006, qualité de l'eau recherche et dénombrement des entérocoques intestinaux dans les eaux d'alimentation humaine : Méthode par filtration sur membrane

12. Afify D.G. Al-Afify and Mohamed Y. M. Aly. Application of Nile Chemical Pollution Index to evaluate the quality of water for drinking and agricultural purposes on Bahr Yusuf Branch, River Nile, Egypt - National Institute of Oceanography and Fisheries, Cairo, Egypt. Egyptian Journal of AquaticBiology\&Fisheries. Vol. 23(1): 367 -379 (2019)

13. Carte Region Rabat Presntaion de la Region Monographie de kenitra.. aspx http://www.equipement.gov.ma/Carte 30/07/2020

14. V.Gbohaida, D. C. P. Agbangnan, M. B. S. Espérance Medoatinsa1, Léonce F. C. Dovonon 1,2, D. Valentin Wotto3, Félicien Avlessi 1 et Dominique C. K. SOHOUNHLOUE 1. Etude de la qualité physico-chimique de l'eau de boisson dans deux localités du Bénin : Cotonou et Dassa-Zoumè Available online at http://www.ifg-dg.org Int. J. Biol. Chem. Sci. 10(1): 422-434, ISSN 1997-342X (Online), ISSN 1991-8631 (Print) (2016)

15. M. Ghaderpoori, Bahramkamarehie, A. Jafari, A. Ghaderpoury and M. Karami. Heavy metals analysis and quality assessment in drinking water Khorramabad city, Iran, Data in Brief, https://doi.org/10.1016/j.dib. (2017)

16. A. El Yemli, N.Berrid, Y.A. Idrissi, A. k. Hussein, F. Al-Nahmi, A. Ghazi. Faculty of Science, Cairo, EgyptISSN 1110 - 6131 Vol. 24(3): 109 - 124 (2020) 